\title{
THE EIMERGENCE OF NOVEL INFLUENZA A VIRUSES OF PUBLIC HEALTH CONCERN IN PAST DECADES
}

\author{
Rashid Manzoor* and Mahmoud Mohamadin
}

Faculty of Health Sciences, Higher Colleges of Technology, Sharjah, United Arab Emirates

*Corresponding author: rmanzoor@hct.ac.ae

\section{INTRODUCTION}

Influenza A viruses (IAVs) belong to Genus Alphainfluenzavirus and family Orthomyxoviridae, and contain single-stranded, negative-sense, segmented genome, comprising of eight segments. The virus particles are spherical to pleomorphic in shape. Each viral RNA molecule is associated with viral polymerase complex (polymerase basic protein 2; $\mathrm{PB} 2$ ), polymerase basic protein $1(\mathrm{~PB} 1)$, polymerase acidic protein (PA)) and nucleoprotein (NP) to form viral ribonucleoprotein particles (McGeoch et al. 1976). In turn, each viral particle encapsidates eight vRNP molecules named as $\mathrm{PB2}_{2}, \mathrm{PB1}_{-}, \mathrm{PA}-$, hemagglutinin (HA)-, NP-, neuraminidase (NA)-, matrix protein (M)- and non-structural protein-(NS)- gene. Approximately $13 \mathrm{~kb}$ genome of IAVs encodes at least 18 viral structural and nonstructural proteins. All viral genes segments, except HA, NA and NP, are so far known to encode only one viral protein (Manzoor et al. 2017). IAVs are divided into serotypes on the basis of combination of surface glycoproteins, named as hemagglutinin (HA) and Neuraminidase (NA). So far, 16 $\mathrm{HA}\left(\mathrm{H}_{1}-\mathrm{H}_{1} 6\right)$ and 9 NA ( $\left.\mathrm{N}_{1}-\mathrm{N}_{9}\right)$ have been identified (Webster et al. 1992; Wille and Holmes 2020).

IAVs have the ability to infect a wide range of avian and mammalian host species. However, traditionally wild aquatic birds and shorebirds are considered as the main natural reservoirs for IAVs. At least, 105 species of wild birds have been identified as natural reservoirs of IAVs. The IAVs are being maintained in the "natural reservoir" via fecal-oral route and the prevalence level can reach up to $20 \%$, or even more during the autumn migration season (Munster et al. 2007; Latorre-Margalef et al. 2014). The recent discovery of novel and highly divergent genome of $\mathrm{H}_{17} \mathrm{~N}_{10}$ and $\mathrm{H}_{18} \mathrm{~N}_{11}$ viruses from fruit bats suggest that wild aquatic birds are not the exclusive influenza $A$ virus reservoirs (Tong et al. 2012; Tong et al. 2013). Occasionally, IAVs leave the natural reservoir, overcome the species barrier through genetic reassortment and/or genetic mutations and cause sporadic infections, epidemics or pandemics in other host species, such as poultry, various mammalian species and even humans (Webster et al. 1992; Wille and Holmes 2020).

Historically, IAVs have caused multiple pandemics. There have been at least 13 pandemics since 1500; and in the past 130 years, the mankind has undoubtedly faced pandemics in 1889, 1918, 1957, 1968, 1977 and 2009 (Morens and Fauci 2007; Taubenberger and Morens 2009). Interestingly, these pandemics, except those of 1968 and 1977, occurred approximately at 40 -years intervals. The worst was the 1918 pandemic that claimed about 50 million human lives worldwide (Taubenberger and Morens 2006). In addition to the pandemics, the IAVs are also responsible for periodic seasonal flue and sporadic outbreaks. It is estimated that seasonal influenza viruses infect $15 \%$ of the human population each year, resulting in $\sim 500$, ooo deaths worldwide (Clem and Galwankar 2009).

Although IAVs show species restriction, sometimes spillover event happens, allowing them to switch to a new host. These spillover events have allowed IAVs to establish new lineages in novel hosts, such as the emergence of swine or equine lineages. The most important of these spillover events is the emergence of novel IAVs causing pandemics in human populations. The adaptation of IAVs to a new host species involves adaptation at multiple levels i.e., entry into the host, attachment and entry into the host cell, successful replication inside the host cells and final release from the host cells and host. In addition to the mutations in the genome of IAVs, genetic reassortment between different IAVs plays a critical role in crossing the species barrier and adaptation to a new host. Following co-infection with different types of IAVs (different lineage or different HA and/or NA subtypes), viral progeny containing many gene segment combinations different from parental viruses is produced. Though many of these combinations will be harmful to the virus, some may facilitate adaptation to the new host. Thus, the emergence of novel IAVs might be a result of within-species reassortment or cross-species reassortment (Wille and Holmes 2020), as shown in Fig. 1. Sometimes, fine-tuning in viral genome facilitated by adaptive mutations is required, especially if an avian virus jumps to a mammalian host. Avian IAVs bind to $\alpha 2$, 3-linked sialic acid receptors with higher affinity, whereas human IAVs bind to $\alpha 2,6$-linked sialic acid receptors with higher affinity. However, recent studies showed that amino acid substitutions Q226L and G228S in receptor binding domain of $\mathrm{H}_{2}$ and $\mathrm{H}_{3}$ subtype IAVs changed the binding preference from avian to human sialic acid receptors. Similarly, A134V, N182S, S223N and R497K mutations in $\mathrm{H}_{5}$ HA were shown to increase viral affinity for human type sialic acid receptors. Human/mammalian adaptation mutations have also been reported in internal genes, such as E627K, D701N in PB2, N375S in PB1 etc. (Schrauwen and Fouchier 2014; Guo et al. 2019).

In recent decades, there have been multiple incidences of the emergence of novel IAVs, and in some instances, human transmissions were also recorded. In the following paragraphs, the avian influenza viruses (AIVs) that have posed a serious threat to public health in the past decades have been discussed. 


\section{A. Within-species Transmission}

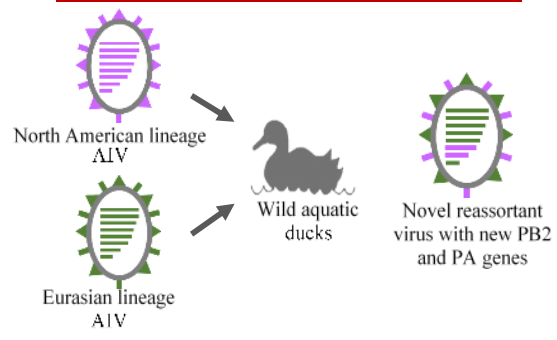

B. Cross-species Transmission

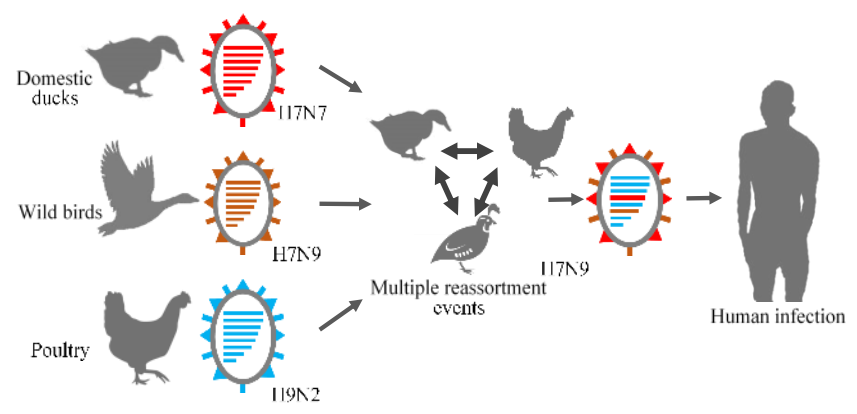

Fig. 1: Emergence of novel IAVs. A. Within-species reassortment of genes occurs when IAVs of different subtypes or lineages coinfect the same species. A/duck/Hokkaido/W95/2006 (H1oN8) virus was isolated from migratory ducks during surveillance in northern Japan. The sequence analysis showed that NA and M genes were of American lineage, while the remaining six genes were of Eurasian lineage (Manzoor et al., 2008). B. Emergence of $\mathrm{H}_{7} \mathrm{~N}_{9}$ influenza virus that infected humans. The virus emerged as a result of multiple reassortment events in domestic ducks, poultry and wild birds. The gene segments of this novel virus are closely related to the viruses found in domestic ducks, wild birds and poultry in Asia (Lam et al., 2013).

\section{H5 subtype IAVs}

Highly pathogenic avian influenza viruses (HPAIVs) have been limited to $\mathrm{H}_{5}$ and $\mathrm{H}_{7}$ HA subtypes, and not all viruses of these subtypes are highly pathogenic for chicken (Manzoor et al. 2008). These $\mathrm{H}_{5}$ and $\mathrm{H}_{7}$ subtypes of avian influenza viruses (AIVs) are maintained in their natural reservoirs as apathogenic avian influenza viruses (APAIVs). Many studies suggest that these APAIV strains are first transmitted to terrestrial poultry, such as domestic waterfowls, quails or turkeys. Then, during multiple transmission events in chicken population, they may acquire pathogenicity for chicken to become HPAIVs (Swayne and Suarez 2000; Ito et al. 2001; Nao et al. 2017). This shift in pathogenicity results from the accumulation of multiple basic amino acids at the HA cleavage site, allowing the virus to gain maturity outside the gastrointestinal tract and establish systemic infection. In 1996, several outbreaks occurred in geese farms at Sanshui, Foshan, a rural area in Guangdong province of China (Wan 2012; Nunez and Ross 2019) and a virus, A/goose/Guangdong/1/1996 $\left(\mathrm{H}_{5} \mathrm{~N}_{1}\right) \quad(\mathrm{Gs} / \mathrm{Gd} / 96)$ was isolated from a sick goose. Later, extensive surveillance for influenza was conducted in Guangdong province between January 1996 and December 1997. Surprisingly, no $\mathrm{H}_{5} \mathrm{~N}_{1}$ HPAI isolate could be detected, suggesting that Gs/Gd/96- like virus probably was not efficiently transmitted among poultry (Zhao et al. 20o8; Wan 2012). Later, Gs/Gd/96-like viruses mutated by genetic reassortment were found to be associated with many outbreaks in poultry. These mutations allowed the viruses to be easily transmitted by fecal-oral route from waterfowl to terrestrial poultry (Webster 2002). In 1997, three chicken farms in Hong Kong were affected by an $\mathrm{H}_{5} \mathrm{~N}_{1} \mathrm{HPAIV}$, with mortality rates ranging between 70 and 100\%. In May 1997, the first human case of a 3-year-old boy infected by a novel $\mathrm{H}_{5} \mathrm{~N}_{1}$ virus was reported in Hong Kong. Later, 17 more human cases were reported between November 1997 and January 1998, raising the concern about potential pandemic (Claas et al. 1998; Subbarao et al. 1998; Bender et al. 1999). Interestingly, there were outbreaks in chicken farms in Hong Kong just before the first and second waves of human infections. Comparison of all gene segments of human and avian isolates, and temporal relationship between avian and human outbreaks, strongly suggested direct chicken-to-human transmission (Claas et al. 1998; Suarez et al. 1998; Subbarao et al. 1998: Shortridge 1999). Later, several studies were conducted to identify the origin of these lethal $\mathrm{H}_{5} \mathrm{~N}_{1}$ viruses isolated in Hong Kong. These studies showed that only HA gene was derived from A/goose/Guangdong/1/1996 ( $\left.\mathrm{H}_{5} \mathrm{~N}_{1}\right)$, whereas other genes might have been derived from locally circulating IAVs, particularly $\mathrm{H}_{9} \mathrm{~N}_{2}$, since both $\mathrm{H}_{5} \mathrm{~N}_{1}$ and $\mathrm{H}_{9} \mathrm{~N}_{2}$ viruses cocirculated in Hong Kong in 1997 (Subbarao et al. 1998; Guan et al. 1999; Xu et al. 1999). Another study suggested that A/teal/Hong Kong/W312/97 (H6N1) might have acted as gene donor, since it showed $>98 \%$ nucleotide homology with six internal genes of A/Hong Kong/156/1997 $\left(\mathrm{H}_{5} \mathrm{~N}_{1}\right)$ (Hoffmann et al. 2000).

Although the 1997 outbreak was controlled by large scale stamping out of 1.5 million poultry in Hong Kong poultry markets, the putative precursor viruses continued to circulate in Hong Kong poultry i.e. $\mathrm{H}_{5} \mathrm{~N}_{1} \mathrm{Gs} / \mathrm{Gd} / 96$-like viruses in geese (Cauthen et al. 2000; Webster et al. 2002) and the $\mathrm{H}_{9} \mathrm{~N}_{2}\left(\mathrm{G}_{1}\right)$ - and $\mathrm{H}_{6} \mathrm{~N}_{1}\left(\mathrm{~W}_{312}\right)$-like viruses in quails (Guan et al. 2000; Chin et al. 2002). Continued surveillance activities in Hong Kong poultry markets during 2000-2001 revealed the existence of multiple genotypes of $\mathrm{H}_{5} \mathrm{~N}_{1}$ viruses that differed from $\mathrm{H}_{5} \mathrm{~N}_{1} / 97$ viruses. The genetic analysis of the isolates suggested that these $\mathrm{H}_{5} \mathrm{~N}_{1} / 2001$ viruses originated as a result of reassortment among viruses from aquatic birds. Until then, these $\mathrm{H}_{5} \mathrm{~N}_{1}$ did not kill their natural hosts and were thought to be in evolutionary state Unexpectedly, in late 2002, these $\mathrm{H}_{5} \mathrm{~N}_{1}$ viruses caused deaths of many resident avian species (such as waterfowls and greater flamingoes), as well as migratory birds (such as egrets, grey herons) in two Hong Kong parks. It was the first report of a fatal case in the natural reservoir since 1996 (Becker 1966). At the same time, $\mathrm{H}_{5} \mathrm{~N}_{1}$ viruses were also isolated from dead chicken in live bird markets and poultry farms in Hong Kong. In 2003, concurrently, $\mathrm{H}_{5} \mathrm{~N}_{1}$ HPAIVs were isolated in China and these viruses displayed higher pathogenicity for ducks in a species dependent manner (Sturm-Ramirez et al. 2005; Pantin-Jackwood and Swayne 2007). In February 2003, $\mathrm{H}_{5} \mathrm{~N}_{1}$ viruses were isolated from two 
humans in Hong Kong (Wuethrich 2003). Since 2003, there had been multiple outbreaks by various genotypes of $\mathrm{H}_{5} \mathrm{~N}_{1}$ viruses across Asia, Europe and Africa. In April June 2005, an outbreak caused by a novel $\mathrm{H}_{5} \mathrm{~N}_{1}$ genetic variant killed more than 6000 wild migratory birds at Lake Qinghai in Southern China and this variant further spread to Middle East, Europe and Africa (Chen et al. 2005; Wang et al. 2008). These outbreaks confirmed the establishment of a new lineage with virulence potential for the natural reservoir. Since January 2003, there have been 862 cases of human infections with $\mathrm{H}_{5} \mathrm{~N}_{1}$ AIVs, reported from 17 countries, with case fatality rate of $53 \%$ (WHO 2021).

The extensive circulation of $\mathrm{H}_{5}$ subtype IAVs has resulted in the emergence of multiple lineages. Therefore, the Southern part of China is considered as a potential influenza epicenter due to its unique ecological system (Shortridge 1997). It is noteworthy to mention that since 1970, at least ten HA subtypes and nine NA subtypes in various combinations have been isolated from ducks and geese in southern China (Wan 2012). These enzootic viruses posed a continuous threat for the emergence of novel AIVs due to potential reassortment with viruses associated with HPAIV outbreaks in poultry and aquatic birds. During 2010-11, a new $\mathrm{H}_{5}$ HA clade (2.3.4.4) emerged. This HA gene displayed a unique tendency to reassort with NA subtypes other than $\mathrm{N}_{1}$, resulting in the emergence of novel AIVs. Since 2010, there were multiple outbreaks of $\mathrm{H}_{5} \mathrm{~N}_{2}, \mathrm{H}_{5} \mathrm{~N}_{3}, \mathrm{H}_{5} \mathrm{~N}_{5}$ and $\mathrm{H}_{5} \mathrm{~N} 8$ HPAIVs in poultry across Asia, Europe and North America. These viruses emerged as a result of reassortment events with $\mathrm{H}_{5} \mathrm{~N}_{1}$ and other circulating viruses, such as $\mathrm{H}_{9} \mathrm{~N}_{2}$, H6N6 etc. (Jhung et al. 2015; Shin et al. 2015; Verhagen et al. 2015; Claes et al. 2016). The $\mathrm{H}_{5} \mathrm{N6}$ IAVs spread to countries in Asia and $\mathrm{H}_{5} \mathrm{~N} 8$ IAVs spread to Europe and North America (Claes et al. 2016). The first laboratory-confirmed case of human infection by $\mathrm{H}_{5} \mathrm{~N} 6$ was reported in April 2014 in Sichuan Province, China. Since then, a total of 32 laboratory-confirmed cases of human infection by $\mathrm{H}_{5} \mathrm{~N} 6$ IAV with 19 deaths have been reported in the Western Pacific region. In February 2021, seven laboratory confirmed cases of human infection by $\mathrm{H}_{5} \mathrm{~N} 8 \mathrm{IAV}$ were reported from Russian Federation (WHO 2021). The human infections by $\mathrm{H}_{5} \mathrm{~N} 6$ and $\mathrm{H}_{5} \mathrm{~N} 8$ viruses were the result of direct contact with infected poultry and no human-to-human spread has been reported.

\section{H6 subtype IAVs}

The first H6 subtype IAV was isolated from turkeys in Massachusetts in 1965. Since then, H6 subtype IAVs have been frequently isolated from aquatic birds and terrestrial poultry from various parts of the world in combination with all NA (N1-N9) subtypes (Downie et al. 1973). Classically, H6 subtype IAVs are responsible for low pathogenic avian influenza virus (LPAIV) infections in poultry. Globally, LPAIV infections by $\mathrm{H6}$ virus are becoming increasingly an economical burden on the poultry industry. In China, H6 subtype AIVs rank second after $\mathrm{H}_{9}$ subtype AIVs in prevalence in aquatic birds and terrestrial poultry (Pepin et al. 2013). According to a surveillance study conducted from 1998-2006 (8 years) on more than 36,0oo wild birds from Europe and the Americas, the H6 was the most abundantly detected influenza virus subtype (Munster et al. 2007). Several studies suggest that H6 subtype IAVs display the broadest host range among all IAVs. More than $30 \%$ of the H6 subtype IAVs isolated from Southern China showed enhanced affinity to human-like $\alpha 2,6$-linked sialic acid receptors (Wang et al. 2014). A study evaluated the replicative potential of 14, non-adapted, H6 subtype AIVs $\left(\mathrm{H}_{6} \mathrm{~N}_{1}, \mathrm{H}_{6} \mathrm{~N}_{2}, \mathrm{H}_{6} \mathrm{~N}_{5}, \mathrm{H} 6 \mathrm{~N} 8\right.$ and $\left.\mathrm{H} 6 \mathrm{~N}_{9}\right)$ in mice. The tested viruses infected the mice and produced neutralizing antibodies (Gillim-Ross et al. 2008). Another study demonstrated the ability of the tested H6 subtype viruses to be transmitted by direct contact between guinea pigs (Wang et al. 2014). Lin et al. (2015) isolated an H6N1 IAV from a dog in Taiwan, and genetic analysis showed that the virus was closely related to the circulating H6 AIVs in Taiwan. So far, there is only one case of human infection reported in 2013 in Taiwan by H6N1 IAV, and the sequence analysis showed that the virus was closely related to the circulating avian $\mathrm{H} 6$ viruses. However, there have been some studies that reported $0.4-2.5 \%$ seroprevalence for H6 HA IAVs among poultry workers (Myers et al. 2007; Quan et al. 2019). These findings clearly warrant the continuous surveillance for $\mathrm{H} 6$ subtype influenza A viruses to avoid any future zoonotic infections.

\section{H7 subtype IAVs}

$\mathrm{H}_{7}$ AIVs have been shown to infect a wide range of host species, encompassing wild and domestic aquatic birds and terrestrial poultry, and mammals including seals, pigs, horses and humans (Abdelwhab et al. 2014; Mostafa et al. 2018; Naguib et al. 2019). Like $\mathrm{H}_{5}$ AIVs, $\mathrm{H}_{7}$ AIVs also can acquire HPAIV potential while circulating in poultry asymptomatically. From infected poultry, human infections with LPAIV or HPAIV have been reported. $\mathrm{H}_{7}$ subtype IAVs of low and high pathogenic potential have caused several outbreaks in poultry (Table 1), with occasional transmissions to humans (Table 2). Before 2003, there were very few cases of human infection by $\mathrm{H}_{7}$ subtype IAVs. Mostly, these cases were reported in laboratory workers. A brief history of various instances of human infections by different $\mathrm{H}_{7} \mathrm{Nx}$ IAVs is discussed below.

$\mathrm{H}_{7} \mathrm{~N}_{2}$

The first evidence of human infection by LPAIV $\mathrm{H}_{7} \mathrm{~N}_{2}$ was reported in a poultry worker in USA during 2002 (Terebuh et al. 2018) and the first LPAIV $\mathrm{H}_{7} \mathrm{~N}_{2}$ was isolated from an immunocompromised patient in USA in 2003 (Ostrowsky et al. 2012). Other instances of human infections by LPAIV $\mathrm{H}_{7} \mathrm{~N}_{2}$ include four humans in 2007 in UK and infection of a veterinarian in a cat shelter in USA in 2016 (Belser et al. 2017; Marinova-Petkova et al. 2017; Naguib et al. 2019).

$\mathrm{H}_{7} \mathrm{~N}_{3}$

Serological analysis using microneutralization assay showed that 7 of 185 poultry workers, who had direct 
Table 1: Outbreaks of LPAI/HPAI caused by $\mathrm{H}_{7}$ subtype viruses in poultry

\begin{tabular}{|c|c|c|c|c|c|}
\hline Country & Year & Subtype & Virulence & Species & Reference \\
\hline$\overline{\mathrm{UK}}$ & 1963 & $\mathrm{H}_{7} \mathrm{~N}_{3}$ & HPAI & Turkeys & (Wells 1963) \\
\hline Australia & 1976 & $\mathrm{H}_{7} \mathrm{~N}_{7}$ & HPAI & Chicken & (Turner 1976) \\
\hline UK & 1979 & $\mathrm{H}_{7} \mathrm{~N}_{7}$ & HPAI & Turkeys & (Alexander et al. 1979) \\
\hline Germany & 1979 & $\mathrm{H}_{7} \mathrm{~N}_{7}$ & HPAI & Chicken & (Rohm et al. 1996) \\
\hline Australia & 1985 & $\mathrm{H}_{7} \mathrm{~N}_{7}$ & HPAI & Chicken & (Barr et al. 1986) \\
\hline Australia & 1992 & $\mathrm{H}_{7} \mathrm{~N}_{3}$ & HPAI & Ducks & (Forsyth et al. 1993) \\
\hline Australia & 1994 & $\mathrm{H}_{7} \mathrm{~N}_{3}$ & HPAI & Chicken & (Dhingra et al. 2018) \\
\hline Pakistan & 1994 & $\mathrm{H}_{7} \mathrm{~N}_{3}$ & HPAI & Chicken & (Naeem and Hussain 1995) \\
\hline USA & $1996-98$ & $\mathrm{H}_{7} \mathrm{~N}_{2}$ & LPAI & Chicken & (Henzler et al. 2003) \\
\hline Australia & 1997 & $\mathrm{H}_{7} \mathrm{~N}_{4}$ & HPAI & Chicken & (Selleck et al. 2003) \\
\hline Ireland & 1998 & $\mathrm{H}_{7} \mathrm{~N}_{7}$ & LPAI & Chicken & (Campbell and De Geus 1999) \\
\hline Northern Ireland & 1998 & $\mathrm{H}_{7} \mathrm{~N}_{7}$ & LPAI & Chicken & (Graham et al. 1999) \\
\hline Italy & 1999-01 & $\mathrm{H}_{7} \mathrm{~N}_{1}$ & HPAI, LPAI & Turkeys & (Capua and Alexander 2004) \\
\hline Canada & 2000 & $\mathrm{H}_{7} \mathrm{~N}_{1}$ & LPAI & Turkeys & (Pasick et al. 2003) \\
\hline Germany & 2001 & $\mathrm{H}_{7} \mathrm{~N}_{7}$ & LPAI & Chicken & (Werner et al. 2003) \\
\hline Pakistan & 2001 & $\mathrm{H}_{7} \mathrm{~N}_{3}$ & HPAI, LPAI & Chicken & (Swayne and Suarez 2001) \\
\hline Chile & 2002 & $\mathrm{H}_{7} \mathrm{~N}_{3}$ & LPAI, HPAI & Chicken & (Rojas et al. 2002) \\
\hline USA & 2002-04 & $\mathrm{H}_{7} \mathrm{~N}_{2}$ & LPAI & Turkeys \& chicken & (Spackman and Suarez 2003) \\
\hline Italy & 2002-03 & $\mathrm{H}_{7} \mathrm{~N}_{3}$ & LPAI & Turkeys & (Capua and Alexander 2004) \\
\hline Pakistan & 2003-04 & $\mathrm{H}_{7} \mathrm{~N}_{3}$ & HPAI & Chicken & (Abbas et al. 2010) \\
\hline The Netherlands & 2003 & $\mathrm{H}_{7} \mathrm{~N}_{7}$ & HPAI & Chicken & (Fouchier et al. 2004) \\
\hline Belgium & 2003 & $\mathrm{H}_{7} \mathrm{~N}_{7}$ & HPAI & Chicken & (Capua and Alexander 2004) \\
\hline Germany & 2003 & $\mathrm{H}_{7} \mathrm{~N}_{7}$ & HPAI & Chicken & (Schrauwen and Fouchier 2014) \\
\hline Canada & 2004 & $\mathrm{H}_{7} \mathrm{~N}_{3}$ & LPAI, HPAI & Chicken & (Hirst et al. 2004) \\
\hline USA (Delaware, Maryland) & 2004 & $\mathrm{H}_{7} \mathrm{~N}_{2}$ & LPAI & Chicken & (Capua and Alexander 2004) \\
\hline Korea & 2005 & $\mathrm{H}_{7} \mathrm{~N}_{7}$ & HPAI & Chicken & (Dhingra et al. 2018) \\
\hline Canada & 2007 & $\mathrm{H}_{7} \mathrm{~N}_{3}$ & HPAI & Chicken & (Berhane et al. 2009) \\
\hline UK & 2008 & $\mathrm{H}_{7} \mathrm{~N}_{7}$ & HPAI & Chicken & (Dhingra et al. 2018) \\
\hline Spain & 2009 & $\mathrm{H}_{7} \mathrm{~N}_{7}$ & HPAI & Chicken & (Iglesias et al. 2010) \\
\hline Mexico & 2012 & $\mathrm{H}_{7} \mathrm{~N}_{3}$ & HPAI & Chicken & (Maurer-Stroh et al. 2013) \\
\hline Australia & 2012 & $\mathrm{H}_{7} \mathrm{~N}_{7}$ & HPAI & Chicken & $(\mathrm{FAO})$ \\
\hline Italy & 2013 & $\mathrm{H}_{7} \mathrm{~N}_{7}$ & HPAI & Chicken & (Bonfanti et al. 2014) \\
\hline Australia & 2013 & $\mathrm{H}_{7} \mathrm{~N}_{2}$ & HPAI & Chicken & (Dhingra et al. 2018) \\
\hline Germany & 2015 & $\mathrm{H}_{7} \mathrm{~N}_{7}$ & HPAI & Chicken & (APHA 2015) \\
\hline UK & 2015 & $\mathrm{H}_{7} \mathrm{~N}_{7}$ & HPAI & Chicken & (APHA 2015) \\
\hline USA & 2015 & $\mathrm{H}_{7} \mathrm{~N} 8$ & HPAI & Turkeys & (Killian et al. 2016) \\
\hline USA & 2017 & $\mathrm{H}_{7} \mathrm{~N}_{9}$ & HPAI & Chicken & (Naguib et al. 2019) \\
\hline
\end{tabular}

Table 2: Human infections by $\mathrm{H}_{7}$ subtype influenza A viruses

\begin{tabular}{|c|c|c|c|c|c|}
\hline Country & Year & Subtype & Pathotype & No. of human cases & Reference \\
\hline USA & 1959 & $\mathrm{H}_{7} \mathrm{~N}_{7}$ & HP & 1 & (Campbell et al. 1970; DeLay et al. 1967) \\
\hline Australia & 1977 & $\mathrm{H}_{7} \mathrm{~N}_{7}$ & $\mathrm{HP}$ & 1 & (Taylor and Turner 1977) \\
\hline USA & $1979-80$ & $\mathrm{H}_{7} \mathrm{~N}_{7}$ & LP & 4 & (Webster et al. 1981) \\
\hline UK & 1996 & $\mathrm{H}_{7} \mathrm{~N}_{7}$ & LP & 1 & (Banks et al. 1998; Kurtz et al. 1996) \\
\hline USA (Virginia) & 2002 & $\mathrm{H}_{7} \mathrm{~N}_{2}$ & LP & $1^{\#}$ & (Terebuh et al. 2018) \\
\hline Italy & 2002-03 & $\mathrm{H}_{7} \mathrm{~N}_{3}$ & LP & $7^{\#}$ & (Puzelli et al. 2005) \\
\hline USA (New York) & 2003 & $\mathrm{H}_{7} \mathrm{~N}_{2}$ & LP & 1 & (Ostrowsky et al. 2012) \\
\hline The Netherlands & 2003 & $\mathrm{H}_{7} \mathrm{~N}_{7}$ & HP & 89 & (Du Ry van Beest Holle et al. 2005; Koopmans et al. 2004) \\
\hline Canada (British Columbia) & 2004 & $\mathrm{H}_{7} \mathrm{~N}_{3}$ & $\mathrm{HP}$ & 2 & (Tweed et al. 2004) \\
\hline UK (Norfolk) & 2006 & $\mathrm{H}_{7} \mathrm{~N}_{3}$ & LP & 1 & (Nguyen-Van-Tam et al. 2006) \\
\hline UK (Wales) & 2007 & $\mathrm{H}_{7} \mathrm{~N}_{2}$ & LP & 4 & (Belser et al. 2017; Naguib et al. 2019) \\
\hline Mexico & 2012 & $\mathrm{H}_{7} \mathrm{~N}_{3}$ & HP & 2 & (Lopez-Martinez et al. 2013) \\
\hline China & 2013 & $\mathrm{H}_{7} \mathrm{~N}_{9}$ & $\mathrm{LP} / \mathrm{HP}$ & 1568 & (WHO 2021) \\
\hline Italy & 2013 & $\mathrm{H}_{7} \mathrm{~N}_{7}$ & $\mathrm{HP}$ & 3 & (Puzelli et al. 2014) \\
\hline USA & 2016 & $\mathrm{H}_{7} \mathrm{~N}_{2}$ & LP & 1 & (Marinova-Petkova et al. 2017) \\
\hline China & 2018 & $\mathrm{H}_{7} \mathrm{~N}_{4}$ & LP & 1 & (Gao et al. 2018; Tong et al. 2018) \\
\hline
\end{tabular}

\# Serologic evidence only

contact with poultry during 2002-03 outbreaks by LPAIV $\mathrm{H}_{7} \mathrm{~N}_{3}$, became seropositive to $\mathrm{H}_{7} \mathrm{HA}$ (Puzelli et al. 2005). In 2004, two laboratory-confirmed human infections with HPAIV $\mathrm{H}_{7} \mathrm{~N}_{3}$ were reported from British Columbia, Canada (Tweed et al. 2004). In 2006 in UK, an LPAIV $\mathrm{H}_{7} \mathrm{~N}_{3}$ was isolated from a poultry worker, who attended an outbreak in poultry by LPAIV $\mathrm{H}_{7} \mathrm{~N}_{3}$, and infection was only limited to conjunctivitis (NguyenVan-Tam et al. 2006). Later, in 2012, two laboratoryconfirmed cases of human infection with HPAIV $\mathrm{H}_{7} \mathrm{~N}_{3}$ were reported from Jalisco, Mexico (Lopez-Martinez et al. 2013). 
$\mathrm{H}_{7} \mathrm{~N}_{4}$

So far, only one case of human infection with LPAIV $\mathrm{H}_{7} \mathrm{~N}_{4}$ has been reported from Jiangsu, China. The virus was isolated from a woman (68-year-old) in February 2018. The entire genome of the virus was of avian origin, and the evidences suggested that the infection was probably acquired directly from poultry during a visit to the live bird market (Gao et al. 2018; Tong et al. 2018).

\section{$\mathrm{H}_{7} \mathrm{~N}_{7}$}

In 1959 in USA, $\mathrm{H}_{7} \mathrm{~N}_{7}$ virus was isolated from the blood of a man diagnosed with infectious hepatitis (DeLay et al. 1967; Campbell et al. 1970). In 1977, a laboratory technician accidentally got infected with $\mathrm{H}_{7}$ virus while handling infectious allantoic fluid (Taylor and Turner 1977). During 1979-80, four technicians got infected after conducting necropsies of the seals died of $\mathrm{H}_{7} \mathrm{~N}_{7}$ infection (Webster et al. 1981). The first evidence of direct avian-to-human transmission of $\mathrm{H}_{7} \mathrm{~N}_{7}$ AIV was reported in 1996 in UK, when one woman developed conjunctivitis after cleaning her duck house (Kurtz et al. 1996; Banks et al. 1998). In 2003 in Netherlands, an outbreak with $\mathrm{H}_{7} \mathrm{~N}_{7}$ HPAIV was reported in poultry farms and human transmission was confirmed by PCR in 86 poultry workers, mostly developed conjunctivitis and/or mild respiratory symptoms. Three households also got the infection from poultry workers, suggesting limited human-to-human transmission. This outbreak also claimed one human life, a veterinarian who visited multiple farms and was hit by the virus (Koopmans et al. 2004; Du Ry van Beest Holle et al. 2005). The genetic analysis showed that the virus had avian origin and was related to previously circulating LPAIVs in ducks (Fouchier et al. 2004). In 2014 in Italy, three cases of human infection with HPAIV $\mathrm{H}_{7} \mathrm{~N}_{7}$ were reported from poultry workers and the clinical signs were only limited to conjunctivitis. The sequence analysis confirmed that all gene segments were closely related to the virus isolated from the same poultry farm (Puzelli et al. 2014).

\section{$\mathrm{H}_{7} \mathrm{~N}_{9}$}

$\mathrm{H}_{7} \mathrm{~N}_{9}$ has caused the highest number of human infections among all reported human infections caused by other than $\mathrm{H}_{7} \mathrm{~N}_{9}$ subtype IAVs. Since March 2013, a total of 1568 laboratory-confirmed human infections with LPAIV $\mathrm{H}_{7} \mathrm{~N}_{9}$ have been reported, including 616 deaths, the case fatality rate was $39 \%$ (WHO 2021). The majority of the cases were reported from China, though a few cases were reported from Taiwan, Malaysia and Canada. So far, there is no evidence of sustained human-to-human transmission of $\mathrm{H}_{7} \mathrm{~N}_{9}$ infection. Since the first report in 2013, there have been 7 waves of infection, mainly occurring in winter. Extensive genetic analysis suggests that the LPAIV $\mathrm{H}_{7} \mathrm{~N}_{9}$ virus originated as a result of several reassortment events between three different AIV subtypes. The zoonotic $\mathrm{H}_{7} \mathrm{~N}_{9}$ virus acquired $\mathrm{HA}$ gene from an $\mathrm{H}_{7} \mathrm{~N}_{7}$ virus, NA gene from an $\mathrm{H}_{7} \mathrm{~N}_{9}$ virus and six remaining genes from an enzootic $\mathrm{H}_{9} \mathrm{~N}_{2}$ virus, as shown in Figure $1 \mathrm{~B}$ (Lam et al. 2013).

\section{Hy subtype IAVs}

The first $\mathrm{H}_{9}$ subtype ( $\left.\mathrm{H}_{9} \mathrm{~N}_{2}\right)$ AIV was isolated from an LPAIV outbreak in turkeys in February 1966 in northern Wisconsin, USA (Homme and Easterday 1970). Later, $\mathrm{H}_{9} \mathrm{~N}_{2}$ viruses were found to be associated with multiple outbreaks, particularly, in turkey production states of Minnesota and Wisconsin (Halvorson et al. 1983; Carnaccini and Perez 2020). Then, in the following years, these viruses were isolated from various parts of Asia and Africa. Three $\mathrm{H}_{9 \mathrm{~N} 2}$ viruses, for the first time, were isolated from terrestrial poultry in 1988 in Hong Kong. Now, these viruses are endemic in many parts of Asia, the Middle East and Africa (Peacock et al. 2019). Like other IAVs, Hy subtype IAVs are also being maintained in wild aquatic birds. Although $\mathrm{H}_{9}$ subtype IAVs have been isolated in combination with all NA ( $\left.\mathrm{N}_{1}-\mathrm{N}_{9}\right)$ subtypes, the huge number of isolated viruses has been reported to be in combination with NA $\mathrm{N}_{2}$ subtype $\left(\mathrm{H}_{9} \mathrm{~N}_{2}\right)$, suggesting the preferred association between $\mathrm{H}_{9}$ and $\mathrm{N}_{2}$ molecules (Yan et al. 2016; Carnaccini and Perez 2020). Due to low pathogenic potential, $\mathrm{H}_{9} \mathrm{~N}_{2}$ viruses are often found cocirculating with other pathogens, like other AIVs subtypes or bacteria, thereby causing significant morbidity and production losses.

Phylogenetically, HA gene of $\mathrm{H}_{9}$ viruses can be divided into two broader lineages i.e., American and Eurasian lineages. $\mathrm{H}_{9}$ viruses belonging to American lineage have mostly been isolated from wild aquatic birds, especially sea birds with sporadic outbreaks in poultry. On the contrary, $\mathrm{H}_{9}$ viruses in the Eurasian lineage are stably circulating in poultry, as well as aquatic birds, with occasional transmission events from wild aquatic to terrestrial poultry. The endemicity of $\mathrm{H}_{9}$ viruses has led to the emergence of phylogenetic diversity, resulting in the emergence of many clades/subclades. Broadly, viruses in a Eurasian lineage can be categorized into the G1-h9.4, BJ94-h9.3 (also known as Y28o or G9) and Y439-h9.2 (Korean) sub-lineages (Guo et al. 2000; Chen et al. 2009; Liu et al. 2009).

The enzootic nature of $\mathrm{H} 9$ viruses in Asia poses a major threat to public health. The first human infection with $\mathrm{H}_{9} \mathrm{~N}_{2}$ AIVs was reported from Hong Kong in 1998 (Peiris et al. 1999). Later, many cases of human infections have been reported from China, Pakistan, Bangladesh, Egypt and Oman (Butt et al. 2005; Chakraborty 2011; Ali et al. 2019; Almayahi et al. 2020). As of $25^{\text {th }}$ June 2021, a total of 59 laboratory-confirmed cases of human infections with $\mathrm{H}_{9} \mathrm{~N}_{2}$ have been reported (WHO 2021). The majority of the infections were reported in young children usually with mild respiratory symptoms. In most human infections, direct or indirect contact with poultry was confirmed. The phylogenetic analysis of human isolates showed that $\mathrm{H}_{9}$ HA gene belonged to $\mathrm{G}_{1}$ or $\mathrm{BJ}_{94}$ sublineages. Additionally, many surveillance studies, conducted among poultry workers in countries where $\mathrm{H}_{9}$ subtype AIVs are endemic, suggested significant exposure 
to Hy subtype IAVs. Fortunately, there has been no report of human-to-human transmission of $\mathrm{H}_{9} \mathrm{~N}_{2}$ viruses (Carnaccini and Perez 2020). However, seroconversion in poultry workers indicates poor management practices in the poultry industry in these countries. It is very important to point out that $\mathrm{H}_{9}$ subtype AIVs have the propensity to donate genes to other AIVs that can cause zoonotic infections, for example, recent $\mathrm{H}_{10 \mathrm{~N}}, \mathrm{H}_{7} \mathrm{~N}_{9}$ and $\mathrm{H}_{5} \mathrm{N6}$ viruses acquired internal gene cassette from circulating $\mathrm{H}_{9} \mathrm{~N}_{2}$ viruses (Lam et al. 2013; Chen et al. 2014).

\section{Ho subtype IAVs}

The first $\mathrm{H}_{10 N}$ AIVs was isolated from a chicken in Germany in 1948 (Feldmann et al. 1988). Since then, H10 AIVs with different NA combinations have been isolated from various species of wild and domestic aquatic and terrestrial birds across the globe. Genetic analysis showed that these Hio AIVs could be grouped into two lineages i.e., Eurasian and North American lineage (Liu et al. 2009; Zhuang et al. 2019). Hio AIVs were thought to infect only avian species. However, in 1984 in Sweden, the first report of infection of farmed minks with $\mathrm{H}_{10 N} 4 \mathrm{AIV}$ was reported. In 2004, two laboratory-conformed cases of human infection (two infants) with $\mathrm{H}_{10 N} N_{7}$ were reported from Egypt. Later, the same virus was isolated from samples collected from wild ducks (Organization. 2004). In 2008, an $\mathrm{H}_{10} \mathrm{~N}_{5}$ AIVs was isolated from pig samples in the slaughterhouse of Hubei province of central China. The genetic analysis showed that the virus was of avian origin and belonged to Eurasian lineage (Wang et al. 2012). In 2010, an outbreak by low pathogenic avian influenza $\mathrm{H}_{10 N}$ virus (LPAIV) was reported from a poultry farm in New South Wales, Australia. Later, the virus was isolated from abattoir workers, who reported conjunctivitis and mild rhinorrhea. The genetic analysis showed that Hio gene belonged to American lineage (Arzey et al. 2012). In 2014, H1oN7 AIV was found to be associated with deaths in harbor seals in Sweden. The phylogenetic analysis showed that Ho gene belonged to Eurasian lineage and clustered with avian viruses isolated from wild aquatic birds (Zohari et al. 2014). Interestingly, all of these events were isolated, short-term and lacked sustained animal-to-animal or human-to-human transmission. Each of the human case had a history of either direct interaction with, or proximity to the live poultry or aquatic birds, and the infections was non-fatal. A novel HioN8 reassortant IAV was isolated in December 2013 from the tracheal aspirate specimen of a patient suffering from pneumonia in Nanchang, Jiangxi province China; the patient passed away 9 days later. Later, three more human infections with HioN8 novel IAV were confirmed, with two of them proved fatal (Chen et al. 2014; Zhang et al. 2015). The high fatality rate caused by the novel HioN8 virus raised a significant public health concern. Extensive surveillance was conducted and H1oN8 AIVs were isolated from wild aquatic birds and terrestrial poultry in live poultry markets (Qi et al. 2014; Zhang et al. 2014). In May 2014, this HioN8 AIV was reported from feral dogs living in close proximity of live bird markets in Guangdong Province, China (Su et al. 2014). Based on extensive genetic analysis, it has been proposed that the HioN8 virus that infected a human emerged as a result of interaction between wild birds and farmed ducks in China, leading to the transfer of Hio and N8 genes to the live poultry markets, where reassortment with enzootic H9N2 viruses occurred. The human infections with H1oN8 viruses were coincident with $\mathrm{H} 10$ virus outbreaks in live poultry markets in China (Ma et al. 2015), and the patients infected with the HioN8 virus had a history of visiting live-poultry markets or exposure to live poultry before disease onset, thus further strengthening the postulate.

\section{Conclusion}

Investigations on most of the recent human infections clearly show that infected people were in direct contact with the poultry and most of these contacts took place in live bird markets. Live bird markets are thought to act as sanctuary for the mixing and reassortment events, since different species of wild and domestic aquatic birds and terrestrial poultry are kept together. A retrospective epidemiological study showed that most patients infected with $\mathrm{H}_{5} \mathrm{~N}_{1}$ visited the live bird market in China (Yu et al. 2007). Therefore, continuous monitoring of IAVs and proper control measures to bring various avian species to these markets is necessary. Moreover, proper training of people involved in handling poultry and poultry products should be made mandatory. Additionally, continuous surveillance activities in wild and domestic aquatic birds should be ensured to monitor the emergence of any novel IAVs and to prevent their transmission to terrestrial poultry.

\section{REFERENCES}

APHA, 2015. Highly pathogenic Avian Influenza $\mathrm{H}_{7} \mathrm{~N}_{7}$ epidemiology report 2015: v6.o.

Abbas MA et al., 2010. Sequence and phylogenetic analysis of $\mathrm{H}_{7} \mathrm{~N}_{3}$ avian influenza viruses isolated from poultry in Pakistan 1995-2004. Virology Journal 7: 137.

Abdelwhab EM et al., 2014. Prevalence and control of $\mathrm{H}_{7}$ avian influenza viruses in birds and humans. Epidemiology and Infection 142: 896-920.

Alexander DJ et al., 1979. Characterisation of influenza viruses isolated from turkeys in Great Britain during 1963-1977. Research in Veterinary Science 26: 17-20.

Ali $\mathrm{M}$ et al., 2019. Avian influenza $\mathrm{A}\left(\mathrm{H}_{9} \mathrm{~N}_{2}\right)$ virus in poultry worker, Pakistan, 2015. Emerging Infectious Diseases 25: 136-139.

Almayahi ZK et al., 2020. First report of human infection with avian influenza $\mathrm{A}\left(\mathrm{H}_{9} \mathrm{~N}_{2}\right)$ virus in Oman: The need for a One Health approach. International Journal of Infectious Diseases 91: 169-173.

Arzey GG et al., 2012. Influenza virus $A\left(\mathrm{H}_{10 N}\right)$ in chickens and poultry abattoir workers, Australia. Emerging Infectious Diseases 18: 814-816.

Banks J et al., 1998. Characterisation of an avian influenza A virus isolated from a human: Is an intermediate 
host necessary for the emergence of pandemic influenza viruses? Archives of Virology 143: 781-787.

Barr DA et al., 1986. Avian influenza on a multi-age chicken farm. Australian Veterinary Journal 63: 195196.

Becker WB, 1966. The isolation and classification of Tern virus: Influenza A-Tern South Africa--1961. Journal of Hygiene 64: 309-320.

Belser JA et al., 2017. A novel $\mathrm{A}\left(\mathrm{H}_{7} \mathrm{~N}_{2}\right)$ influenza virus isolated from a veterinarian caring for cats in a New York city animal shelter causes mild disease and transmits poorly in the ferret model. Journal of Virology 91(15): eoo672-17; doi: 10.1128/JVL.0o672-17.

Bender C et al., 1999. Characterization of the surface proteins of influenza $A\left(\mathrm{H}_{5} \mathrm{~N}_{1}\right)$ viruses isolated from humans in 1997-1998. Virology 254: 115-123.

Berhane $Y$ et al., 2009. Highly pathogenic avian influenza virus $A\left(\mathrm{H}_{7} \mathrm{~N}_{3}\right)$ in domestic poultry, Saskatchewan, Canada, 2007. Emerging Infectious Diseases 15: 14921495.

Bonfanti L et al., 2014. Highly pathogenic $\mathrm{H}_{7} \mathrm{~N}_{7}$ avian influenza in Italy. Veterinary Record 174: 382.

Butt KM et al., 2005. Human infection with an avian $\mathrm{H}_{9} \mathrm{~N}_{2}$ influenza A virus in Hong Kong in 2003. Journal of Clinical Microbiology 43: 5760-5767.

Campbell $\mathrm{CH}$ et al., 1970. Fowl plague virus from man. Journal of Infectious Diseases 122: 513-516.

Campbell G and De Geus H, 1999. Non-pathogenic avian influenza in Ireland in 1998. Proceedings of the Joint Fifth Annual Meetings of the National Newcastle Disease and Avian Influenza Laboratories of Countries of the European Union, 1998, Vienna, Austria; 9-10 November 1999, pp: 13-15.

Capua I and Alexander DJ, 2004. Avian influenza: Recent developments. Avian Pathology 33: 393-404.

Carnaccini S and Perez DR, 2020. Hy influenza viruses: An emerging challenge. Cold Spring Harbor Perspectives in Medicine 10(6): ao38588.

Cauthen AN et al., 200o. Continued circulation in China of highly pathogenic avian influenza viruses encoding the hemagglutinin gene associated with the $1997 \mathrm{H}_{5} \mathrm{~N}_{1}$ outbreak in poultry and humans. Journal of Virology 74: 6592-6599.

Chakraborty A, 2011. Outbreak of mild respiratory disease caused by $\mathrm{H}_{5} \mathrm{~N}_{1}$ and $\mathrm{H}_{9} \mathrm{~N}_{2}$ infections among young children in Dhaka, Bangladesh, 2011. Health and Science Bulletin 9: 5-12.

Chen $\mathrm{H}$ et al., 2005. Avian flu: $\mathrm{H}_{5} \mathrm{~N}_{1}$ virus outbreak in migratory waterfowl. Nature 436: 191-192.

Chen $\mathrm{H}$ et al., 2014. Clinical and epidemiological characteristics of a fatal case of avian influenza A HioN8 virus infection: A descriptive study. The Lancet 383: 714-721.

Chen JM et al., 2009. Panorama phylogenetic diversity and distribution of type A influenza viruses based on their six internal gene sequences. Virology Journal 6: 137.

Chin PS et al., 2002. Molecular evolution of H6 influenza viruses from poultry in Southeastern China: prevalence of $\mathrm{H}_{6} \mathrm{~N}_{1}$ influenza viruses possessing seven
A/Hong Kong/156/97 ( $\left.\mathrm{H}_{5} \mathrm{~N}_{1}\right)$-like genes in poultry. Journal of Virology 76: 507-516.

Claas EC et al., 1998. Human influenza A $\mathrm{H}_{5} \mathrm{~N}_{1}$ virus related to a highly pathogenic avian influenza virus. The Lancet 351: 472-477.

Claes F et al., 2016. Emergence and dissemination of clade 2.3.4.4 $\mathrm{H}_{5} \mathrm{Nx}$ influenza viruses-how is the Asian HPAI $\mathrm{H}_{5}$ lineage maintained. Current Opinion in Virology 16: 158-163.

Clem A and Galwankar S, 2009. Seasonal influenza: Waiting for the next pandemic. Journal of Global Infectious Diseases 1: 51-56.

DeLay PD et al., 1967. Comparative study of fowl plague virus and a virus isolated from man. Public Health Reports 82: 615-620.

Dhingra MS et al., 2018. Geographical and historical patterns in the emergences of novel highly pathogenic avian influenza (HPAI) $\mathrm{H}_{5}$ and $\mathrm{H}_{7}$ viruses in poultry. Frontiers in Veterinary Science 5: 84.

Downie J et al., 1973. Characterization and ecology of a type A influenza virus isolated from a shearwater. Bulletin of the World Health Organization 49: 559566.

Du Ry van Beest Holle M, et al., 2005. Human-to-human transmission of avian influenza $\mathrm{A} / \mathrm{H}_{7} \mathrm{~N}_{7}$, The Netherlands, 2003. Euro Surveillance 10: 3-4.

Feldmann $\mathrm{H}$ et al., 1988. The structure of serotype Hio hemagglutinin of influenza A virus: Comparison of an apathogenic avian and a mammalian strain pathogenic for mink. Virology 165: 428-437.

Forsyth WM et al., 1993. Diagnosis of highly pathogenic avian influenza in chickens: Bendigo 1992. Australian Veterinary Journal 70: 118-119.

Fouchier RA et al., 2004. Avian influenza A virus $\left(\mathrm{H}_{7} \mathrm{~N}_{7}\right)$ associated with human conjunctivitis and a fatal case of acute respiratory distress syndrome. Proceedings of the National Academy of Sciences of the United States of America 101: 1356-1361.

Gao P et al., 2018. Human infection with an avian-origin influenza $\mathrm{A}\left(\mathrm{H}_{7} \mathrm{~N}_{4}\right)$ virus in Jiangsu: A potential threat to China. Journal of Infection 77: 249-257.

Gillim-Ross L et al., 20o8. Avian influenza H6 viruses productively infect and cause illness in mice and ferrets. Journal of Virology 82: 10854-10863.

Graham D et al., 1999. Avian influenza in Northern Ireland: Current situation. Proceedings of the Joint Fifth Annual Meetings of the National Newcastle Disease and Avian Influenza Laboratories of Countries of the European Union, 1998, Vienna, Austria; 9-10 November 1999, pp: 18-19.

Guan Y et al., 1999. Molecular characterization of $\mathrm{H}_{9} \mathrm{~N}_{2}$ influenza viruses: Were they the donors of the "internal" genes of $\mathrm{H}_{5} \mathrm{~N}_{1}$ viruses in Hong Kong? Proceedings of the National Academy of Sciences of the United States of America 96: 9363-9367.

Guan Y et al., 200o. $\mathrm{H}_{9} \mathrm{~N}_{2}$ influenza viruses possessing $\mathrm{H}_{5} \mathrm{~N}_{1}$-like internal genomes continue to circulate in poultry in southeastern China. Journal of Virology 74: 9372-9380. 
Guo F et al., 2019. Adaptive evolution of human-isolated $\mathrm{H}_{5} \mathrm{Nx}$ avian influenza A viruses. Frontiers in Microbiology 10: 1328.

Guo YJ et al., 200o. Characterization of the pathogenicity of members of the newly established $\mathrm{H}_{9} \mathrm{~N}_{2}$ influenza virus lineages in Asia. Virology 267: 279-288.

Halvorson D et al., 1983. Epizootiology of avian influenza-simultaneous monitoring of sentinel ducks and turkeys in Minnesota. Avian Diseases 27: 77-85.

Henzler DJ et al., 2003. Epidemiology, production losses, and control measures associated with an outbreak of avian influenza subtype $\mathrm{H}_{7} \mathrm{~N}_{2}$ in Pennsylvania (199698). Avian Diseases 47: 1022-1036.

Hirst $\mathrm{M}$ et al., 2004. Novel avian influenza $\mathrm{H}_{7} \mathrm{~N}_{3}$ strain outbreak, British Columbia. Emerging Infectious Diseases 10: 2192-2195.

Hoffmann E et al., 20oo. Characterization of the influenza A virus gene pool in avian species in southern China: Was $\mathrm{H}_{6} \mathrm{~N}_{1}$ a derivative or a precursor of $\mathrm{H}_{5} \mathrm{~N}_{1}$ ? Journal of Virology 74: 6309-6315.

Homme PJ and Easterday BC, 1970. Avian influenza virus infections. I. Characteristics of influenza A-turkeyWisconsin-1966 virus. Avian Diseases 14: 66-74.

Iglesias I et al., 2010. First case of highly pathogenic avian influenza in poultry in Spain. Transboundary and Emerging Diseases 57: 282-285.

Ito $\mathrm{T}$ et al., 2001. Generation of a highly pathogenic avian influenza A virus from an avirulent field isolate by passaging in chickens. Journal of Virology 75: 44394443.

Jhung MA et al., 2015. Outbreaks of avian influenza A $\left(\mathrm{H}_{5} \mathrm{~N}_{2}\right),\left(\mathrm{H}_{5} \mathrm{~N} 8\right)$, and $\left(\mathrm{H}_{5} \mathrm{~N}_{1}\right)$ among birds--United States, December 2014-January 2015. Morbidity and Mortality Weekly Report 64: 111.

Killian ML et al., 2016. Outbreak of $\mathrm{H}_{7} \mathrm{~N} 8$ low pathogenic avian influenza in commercial turkeys with spontaneous mutation to highly pathogenic avian influenza. Genome Announcements 4(3): eoo457-16; doi: 10.1128/genomeA.00457-16.

Koopmans $\mathrm{M}$ et al., 2004. Transmission of $\mathrm{H}_{7} \mathrm{~N}_{7}$ avian influenza A virus to human beings during a large outbreak in commercial poultry farms in the Netherlands. The Lancet 363: 587-593.

Kurtz J et al., 1996. Avian influenza virus isolated from a woman with conjunctivitis. The Lancet 348: 901-902.

Lam TT et al., 2013. The genesis and source of the $\mathrm{H}_{7} \mathrm{~N}_{9}$ influenza viruses causing human infections in China. Nature 502: 241-244.

Latorre-Margalef $\mathrm{N}$ et al., 2014. Long-term variation in influenza A virus prevalence and subtype diversity in migratory mallards in northern Europe. Proceedings of the royal Society B: Biological Sciences 281: 20140098.

Lin HT et al., 2015. Influenza $\mathrm{A}\left(\mathrm{H} 6 \mathrm{~N}_{1}\right)$ virus in dogs, Taiwan. Emerging Infectious Diseases 21: 2154-2157.

Liu $S$ et al., 2009. Panorama phylogenetic diversity and distribution of Type A influenza virus. PloS One 4: e5022.

Lopez-Martinez I et al., 2013. Highly pathogenic avian influenza $\mathrm{A}\left(\mathrm{H}_{7} \mathrm{~N}_{3}\right)$ virus in poultry workers, Mexico,
2012. Emerging Infectious Diseases 19: 1531-1534.

$\mathrm{Ma} \mathrm{C}$ et al., 2015. Emergence and evolution of Hio subtype influenza viruses in poultry in China. Journal of Virology 89: 3534-3541.

Manzoor $\mathrm{R}$ et al., 2017. Influenza A virus M2 protein: Roles from ingress to egress. International Journal of Molecular Sciences 18(12): 2649.

Manzoor R et al., 20o8. Development of a pen-site test kit for the rapid diagnosis of $\mathrm{H}_{7}$ highly pathogenic avian influenza. Journal of Veterinary Medical Science 70: 557-562.

Marinova-Petkova A et al., 2017. Avian influenza $\mathrm{A}\left(\mathrm{H}_{7} \mathrm{~N}_{2}\right)$ virus in human exposed to sick cats, New York, USA, 2016. Emerging Infectious Diseases 23(12): 2046-2049.

Maurer-Stroh S et al., 2013. The highly pathogenic $\mathrm{H}_{7} \mathrm{~N}_{3}$ avian influenza strain from July 2012 in Mexico acquired an extended cleavage site through recombination with host $28 \mathrm{~S}$ rRNA. Virology Journal 10: 139 .

McGeoch D et al., 1976. Influenza virus genome consists of eight distinct RNA species. Proceedings of the National Academy of Sciences of the United States of America 73: 3045-3049.

Morens DM and Fauci AS, 2007. The 1918 influenza pandemic: Insights for the 21st century. Journal of Infectious Diseases 195: 1018-1028.

Mostafa A et al., 2018. Zoonotic potential of influenza A viruses: A comprehensive overview. Viruses 10(9): 497.

Munster VJ et al., 2007. Spatial, temporal, and species variation in prevalence of influenza A viruses in wild migratory birds. PLoS Pathogens 3: e61.

Myers KP et al., 2007. Infection due to 3 avian influenza subtypes in United States veterinarians. Clinical Infectious Diseases 45: 4-9.

Naeem K and Hussain M, 1995. An outbreak of avian influenza in poultry in Pakistan. Veterinary Record 137: 439.

Naguib MM et al., 2019. Global patterns of avian influenza A $\left(\mathrm{H}_{7}\right)$ : Virus evolution and zoonotic threats. FEMS Microbiology Reviews 43: 6o8-621.

Nao $\mathrm{N}$ et al., 2017. Genetic predisposition to acquire a polybasic cleavage site for highly pathogenic avian influenza virus hemagglutinin. mBio 8(1): eo2298-16; doi: $10.1128 / \mathrm{mBio.02298-16.}$

Nguyen-Van-Tam JS et al., 2006. Outbreak of low pathogenicity $\mathrm{H}_{7} \mathrm{~N}_{3}$ avian influenza in UK, including associated case of human conjunctivitis. Euro Surveillance 11: Eo6o504.2; doi: 10.2807/esw.11.18.029 52-en.

Nunez IA and Ross TM, 2019. A review of $\mathrm{H}_{5} \mathrm{Nx}$ avian influenza viruses. Therapeutic Advances in Vaccines and Immunotherapy 7: 2515135518821625.

Organization. PAH, 2004. Avian influenza virus A $\left(\mathrm{H}_{10 N}\right)$ circulating among humans in Egypt. Pan American Health Organization 2(18): 07 May 2004.

Ostrowsky B et al., 2012. Low pathogenic avian influenza A $\left(\mathrm{H}_{7} \mathrm{~N}_{2}\right)$ virus infection in immunocompromised adult, New York, USA, 2003. Emerging Infectious Diseases 18: 1128-1131. 
Pantin-Jackwood MJ and Swayne DE, 2007. Pathobiology of Asian highly pathogenic avian influenza $\mathrm{H}_{5} \mathrm{~N}_{1}$ virus infections in ducks. Avian Diseases 51: 250-259.

Pasick J et al., 2003. Characterization of avian influenza virus isolates submitted to the National Centre for Foreign Animal Disease between 1997 and 20o1. Avian Diseases 47: 1208-1213.

Peacock THP et al., 2019. A global perspective on $\mathrm{H}_{9} \mathrm{~N}_{2}$ avian influenza virus. Viruses 11(7): 620.

Peiris $M$ et al., 1999. Human infection with influenza H9N2. The Lancet 354: 916-917.

Pepin KM et al., 2013. Multiannual patterns of influenza A transmission in Chinese live bird market systems. Influenza and Other Respiratory Viruses 7: 97-107.

Puzelli S et al., 2005. Serological analysis of serum samples from humans exposed to avian $\mathrm{H}_{7}$ influenza viruses in Italy between 1999 and 2003. Journal of Infectious Diseases 192: 1318-1322.

Puzelli S et al., 2014. Human infection with highly pathogenic $\mathrm{A}\left(\mathrm{H}_{7} \mathrm{~N}_{7}\right)$ avian influenza virus, Italy, 2013. Emerging Infectious Diseases 20: 1745-1749.

Qi W et al., 2014. Genesis of the novel human-infecting influenza $\mathrm{A}(\mathrm{H} 1 \mathrm{ON} 8)$ virus and potential genetic diversity of the virus in poultry, China. Euro Surveillance 19(25): 20841.

Quan C et al., 2019. Avian influenza A viruses among occupationally exposed populations, China, 2014-2016. Emerging Infectious Diseases 25: 2215-2225.

Rohm C et al., 1996. Different hemagglutinin cleavage site variants of $\mathrm{H}_{7} \mathrm{~N}_{7}$ in an influenza outbreak in chickens in Leipzig, Germany. Virology 218: 253-257.

Rojas $\mathrm{H}$ et al., 2002. Avian influenza in poultry in Chile. Veterinary Record 151: 188.

Schrauwen EJ and Fouchier RA, 2014. Host adaptation and transmission of influenza $A$ viruses in mammals. Emerging Microbes and Infections 3: e9; doi: 10.1038/emi.2014.9.

Selleck PW et al., 2003. An outbreak of highly pathogenic avian influenza in Australia in 1997 caused by an $\mathrm{H}_{7} \mathrm{~N}_{4}$ virus. Avian Diseases 47: 806-811.

Shin JH et al., 2015. Prevalence of avian influenza virus in wild birds before and after the HPAI $\mathrm{H}_{5} \mathrm{~N} 8$ outbreak in 2014 in South Korea. Journal of Microbiology 53: 475-480.

Shortridge KF, 1997. Is China an influenza epicentre? Chinese Medical Journal (Engl.) 110: 637-641.

Shortridge KF, 1999. Poultry and the influenza $\mathrm{H}_{5} \mathrm{~N}_{1}$ outbreak in Hong Kong, 1997: Abridged chronology and virus isolation. Vaccine 17 (Supplement 1): S26-29.

Spackman E and Suarez DL, 2003. Evaluation of molecular markers for pathogenicity in recent $\mathrm{H}_{7} \mathrm{~N}_{2}$ avian influenza isolates from the northeastern United States. Proceedings of the 52nd WPDC Sacramento, CA, USA; 8-11 March 2003, pp: 21-23.

Sturm-Ramirez KM et al., 2005. Are ducks contributing to the endemicity of highly pathogenic $\mathrm{H}_{5} \mathrm{~N}_{1}$ influenza virus in Asia? Journal of Virology 79: 11269-11279.

Su S et al., 2014. First evidence of HioN8 avian influenza virus infections among feral dogs in live poultry markets in Guangdong province, China. Clinical
Infectious Diseases 59: 748-750.

Suarez DL et al., 1998. Comparisons of highly virulent $\mathrm{H}_{5} \mathrm{~N}_{1}$ influenza A viruses isolated from humans and chickens from Hong Kong. Journal of Virology 72: 6678-6688.

Subbarao K et al., 1998. Characterization of an avian influenza $A\left(\mathrm{H}_{5} \mathrm{~N}_{1}\right)$ virus isolated from a child with a fatal respiratory illness. Science 279: 393-396.

Swayne DE and Suarez DL, 200o. Highly pathogenic avian influenza. Revue Scientifique et Technique 19: 463482.

Swayne DE and Suarez DL, 2001. Avian influenza in Europe, Asia and Central America during 2001. Proceedings of the 105th Annual Meeting of the US Animal Health Association, Hershey, Pennsylvania; 18 November 2001, pp: 465-470.

Taubenberger JK and Morens DM, 2006. 1918 Influenza: The mother of all pandemics. Emerging Infectious Diseases 12: 15-22.

Taubenberger JK and Morens DM, 2009. Pandemic influenza--including a risk assessment of $\mathrm{H}_{5} \mathrm{~N}_{1}$. Revue Scientifique et Technique 28: 187-202.

Taylor HR and Turner AJ, 1977. A case report of fowl plague keratoconjunctivitis. British Journal of Ophthalmology 61: 86-88.

Terebuh $\mathrm{P}$ et al., 2018. Human infection with avian influenza $\mathrm{A}\left(\mathrm{H}_{7} \mathrm{~N}_{2}\right)$ virus-Virginia, 2002. Influenza and other Respiratory Viruses 12: 529-532.

Tong $\mathrm{S}$ et al., 2012. A distinct lineage of influenza A virus from bats. Proceedings of the National Academy of Sciences of the United States of America 109: 42694274.

Tong $S$ et al., 2013. New world bats harbor diverse influenza A viruses. PLoS Pathogens 9: e1003657.

Tong XC et al., 2018. First human infection by a novel avian influenza $\mathrm{A}\left(\mathrm{H}_{7} \mathrm{~N}_{4}\right)$ virus. Journal of Infection 77 : 249-257.

Turner AJ, 1976. The isolation of fowl plague virus in Victoria. Australian Veterinary Journal 52: 384.

Tweed SA et al., 2004. Human illness from avian influenza $\mathrm{H}_{7} \mathrm{~N}_{3}$, British Columbia. Emerging Infectious Diseases 10: 2196-2199.

Verhagen JH et al., 2015. Wild bird surveillance around outbreaks of highly pathogenic avian influenza $\mathrm{A}\left(\mathrm{H}_{5} \mathrm{~N} 8\right)$ virus in the Netherlands, 2014, within the context of global flyways. Euro Surveillance 20(12): 21069.

Wan XF, 2012. Lessons from emergence of A/goose/Guangdong/1996-like $\mathrm{H}_{5} \mathrm{~N}_{1}$ highly pathogenic avian influenza viruses and recent influenza surveillance efforts in southern China. Zoonoses and Public Health 59(Supplement 2): 32-42.

Wang $\mathrm{G}$ et al., 2008. $\mathrm{H}_{5} \mathrm{~N}_{1}$ avian influenza re-emergence of Lake Qinghai: Phylogenetic and antigenic analyses of the newly isolated viruses and roles of migratory birds in virus circulation. Journal of General Virology 89: 697-702.

Wang G et al., 2014. H6 influenza viruses pose a potential threat to human health. Journal of Virology 88: 39533964 . 
Wang $\mathrm{N}$ et al., 2012. Complete genome sequence of an $\mathrm{H}_{1} \mathrm{~N}_{5}$ avian influenza virus isolated from pigs in central China. Journal of Virology 86: 13865-13866.

Webster RG et al., 1981. Conjunctivitis in human beings caused by influenza A virus of seals. New England Journal of Medicine 304: 911.

Webster RG et al., 1992. Evolution and ecology of influenza A viruses. Microbiological Reviews 56: 152179.

Webster RG, 2002. The importance of animal influenza for human disease. Vaccine 20(Supplement 2): S16-20.

Webster RG et al., 2002. Characterization of $\mathrm{H}_{5} \mathrm{~N}_{1}$ influenza viruses that continue to circulate in geese in southeastern China. Journal of Virology 76: 118-126.

Wells RJH, 1963. An outbreak of fowl plague in turkeys. Veterinary Record 75: 783-786.

Werner $\mathrm{O}$ et al., 2003. Isolation and characterization of a low-pathogenicity $\mathrm{H}_{7} \mathrm{~N}_{7}$ influenza virus from a turkey in a small mixed free-range poultry flock in Germany. Avian Diseases 47: 1104-1106.

WHO, 2021. Avian influenza weekly update Number 798 .

Wille $\mathrm{M}$ and Holmes EC, 2020. The ecology and evolution of influenza viruses. Cold Spring Harbor Perspectives in Medicine 10(7): a038489.

Wuethrich B, 2003. Infectious disease. An avian flu jumps to people. Science 299: 1504 .
$\mathrm{Xu} \mathrm{X}$ et al., 1999. Genetic characterization of the pathogenic influenza A/Goose/Guangdong/1/96 $\left(\mathrm{H}_{5} \mathrm{~N}_{1}\right)$ virus: Similarity of its hemagglutinin gene to those of $\mathrm{H}_{5} \mathrm{~N}_{1}$ viruses from the 1997 outbreaks in Hong Kong. Virology 261: 15-19.

Yan L et al., 2016. Pathogenicity of reassortant $\mathrm{H}_{9}$ influenza viruses with different NA genes in mice and chickens. Veterinary Research 47: 67.

$\mathrm{Yu} \mathrm{H}$ et al., 2007. Human influenza A $\left(\mathrm{H}_{5} \mathrm{~N}_{1}\right)$ cases, urban areas of People's Republic of China, 2005-2006. Emerging Infectious Diseases 13: 1061-1064.

Zhang $\mathrm{H}$ et al., 2015. A human-infecting HioN8 influenza virus retains a strong preference for avian-type receptors. Cell Host \& Microbe 17: 377-384.

Zhang $\mathrm{T}$ et al., 2014. Human infection with influenza virus A(HoN8) from live poultry markets, China, 2014. Emerging Infectious Diseases 20: 2076-2079.

Zhao ZM et al., 2008. Genotypic diversity of $\mathrm{H}_{5} \mathrm{~N}_{1}$ highly pathogenic avian influenza viruses. Journal of General Virology 89: 2182-2193.

Zhuang Q et al., 2019. Diversity and distribution of type A influenza viruses: An updated panorama analysis based on protein sequences. Virology Journal 16: 85 .

Zohari $\mathrm{S}$ et al., 2014. Avian influenza $\mathrm{A}\left(\mathrm{H}_{10 N}\right)$ virus involvement in mass mortality of harbour seals (Phoca vitulina) in Sweden, March through October 2014. Euro Surveillance 19(46): 20967. 